\title{
Considerations regarding the necessity of adapting the physical therapy approach to optimize the quality of life of paraplegic persons
}

\author{
Ioan Cosmin Boca ${ }^{1}$, Mirela Dan ${ }^{2}$ \\ 1, 2 “Vasile Goldiş” Western University, Arad, 310025, Romania. \\ icboca@yahoo.com
}

\begin{abstract}
A pathological manifestation of such a magnitude as the spinal cord injury is undoubtedly one of the most devastating biological disasters for the human being, severity of the disability of paraplegic persons becoming a major goal of rehabilitation services everywhere, this condition requiring significant personal and socio-economic costs. Unfortunately currently there are no medical solutions for restoring damaged spine area, although there are teams of researchers studying the possibility of nerve grafting, stem cells implant or bone marrow electrostimulation devices implant. The conditions are that such therapies will be available in the future. A complex kinetic approach which initially surprises, as detailed and accurate as possible, the whole picture of various morphological, functional and pathological manifestations after spinal cord injury, through an accurate and relevant specific assessment protocol, and which lately acts, using specific methods, towards the restoration of functional balance, can improve the functional development of paraplegic patient, reflected by an increase in the level of physical activity with direct implications for quality of life of these individuals. Let us not forget that the primary goal of rehabilitation is to teach paraplegic persons to help themselves, which means to make those people to fully use their available functionality to compensate for the functions and accept their disability. Paraplegic patient must be aware of the fact that he possesses plenty of helpful resources for him and for those around him and that life can give him enough satisfactions even if his the mode of locomotion is changed.
\end{abstract}

\section{Introducere}

Starea de bine, sănătatea şi completa independenţă funcţională sunt bunuri de mare preț, pe care, oricât de multă grijă am avea, mai devreme sau mai târziu, mai rapid sau mai lent, treptat sau dintr-o dată, le vom pierde.

O manifestare patologică de o asemenea amploare precum leziunea măduvei spinării constituie, indubitabil, una dintre cele mai devastatoare dezastre biologice pentru fiinţa umană, severitatea invalidităţii persoanelor paraplegice devenind astfel un obiectiv major al serviciilor de recuperare de pretutindeni, această afecţiune impunând importante costuri socio-economice şi personale.
Fiecare epocă s-a confruntat cu chestiunea morală și politică legată de atitudinea faţă de persoanele cu dizabilităţi.

Din păcate istoria a fost chiar tragică pentru aceste persoane, mai ales la începuturile umanităţii.

Tratarea discriminatorie a persoanelor cu paraplegie are o istorie lungă, începând cu atitudinea manifestată în antichitate în Grecia, Roma sau în societatea evreiască şi continuând apoi cu societatea creştină. Secolul XIX a adus importante transformări ale societăţii, incluzând aici şi amploarea înregistrată de conștientizarea socială a problemelor persoanelor cu dizabilităţi, concretizată prin deschiderea de școli și centre de tratament pentru aceste persoane. 
În ultima jumătate de veac a început să fie evidenţiată o nouă atitudine din partea societăţii şi implicit a furnizorilor de servicii medicale specializate şi anume promovarea independenţei funcţionale.

Aşadar atitudinea faţă de persoanele cu disabilităţi s-a schimbat de-a lungul timpului graţie şi apariţiei şi dezvoltării unor profesiuni, printre acestea şi a terapiei ocupaţionale, care au modificat balanţa între atitudinea de ajutorare şi cea de represiune şi au înlocuit-o acum cu cea de creare de oportunităţi de dezvoltarea a independenţei persoanelor cu disabilităţi.

Terapia ocupaţională se adresează tuturor pesoanelor care din diverse motive medicale prezintă dificultăţi de integrare şi are ca scop câştigarea potenţialului maxim pentru independenţă şi productivitate în viaţa acestora.

Prin intermediul terapiei ocupaţionale persoanele cu disabilităţi sunt ajutate să se adapteze mediului în care trăiesc sau să folosească mediul special adaptat pentru nevoile personale, astfel încât aceste persoane să devină capabile să-şi desfăşoare în continuare viaţa cu demnitate şi autorespect. Obiectivul terapiei ocupaţionale, în privinţa persoanele cu paraplegie este cel de integrare deplină a acestora, o integrare care vizează toate dimensiunile: fizică, funcţională, socială, personală şi socială.

Leziunea măduvei spinării, în funcţie de localizarea şi intensitatea ei, determină apariţia unor tulburări de mişcare şi perturbarea funcţionalităţii bolnavului, ambele fiind asociate cu o scădere a calității vietii bolnavului cu paraplegie.

În general, paraplegia are şanse mici de recuperare, cu excepţia cazurilor în care întreruperea conducerii nervoase la nivel medular a fost doar funcţională, structurile anatomice rămânând integre [1].

Din păcate în momentul actual nu există soluţii medicale pentru refacerea zonei de măduvă lezate, deşi există echipe de cercetători care studiază posibilitatea grefării nervoase, implantul de celule stem sau implantul de dispozitive electrostimulante la nivelul măduvei. Există premise ca astfel de terapii vor fi posibile în viitor.

În programul de recuperare al pacienţilor paraplegici reeducarea neuro-motorie reprezintă doar un aspect, problemele medicale ale acestor bolnavi fiind extrem de complexe, aparţinând diverselor specialităţi neuro-chirurgicale, neurologice, urologice, ale terapiei ocupaţionale şi psihologiei.

Acţiunea de recuperare funcţională presupune deci o activitate de echipă în care fiecare specialist trebuie să-şi aducă aportul pentru îndeplinirea obiectivelor propuse. [2]

Paraplegicul va primi de obicei suport de la o echipa medicală multidisciplinară ce poate include mai multi medici (neurochirurgi, urologi, chirurgi ortopezi, specialişti în recuperare şi pediatrie), un asistent medical specializat în recuperare, specialişti în kinetoterapie şi terapie ocupaţională şi un asistent social. Scopul primordial al reabilitării funcţionale în cazul acestor persoane este de a crea un stil de viaţă pentru pacient şi famile astfel ca dizabilitatea să interfereze cât mai puţin cu activităţile zilnice normale

\section{Discuţii}

Deşi intervențiile de reabilitare funcţională care promovează recuperarea funcțiilor pierdute prin implementarea utilizării tehnicilor compensatorii și a echipamentelor adaptative au fost corelate pozitiv cu îmbunătăţirea calităţii vieţii pentru persoanelor paraplegice [3], nivelul calităţii vieții acestor persoane rămâne cu mult sub nivelul observat la populațiile similare care nu prezintă lezuni la nivelul măduvei spinării [4]. De exemplu, Kannisto şi colab. [5], constată în urma unui studiu că persoanele paraplegice au prezentat scoruri ale calităţii vieții cu aproape $10 \%$ mai mici decât cele înregistrate la adulţii sănătoşi, rezultate similare fiind obţinute de asemenea de Post şi colab. [6], care au raportat scoruri generale ale calităţii vieții, 
care au fost mai mici decât valorile găsite în populația generală.

Având în vedere aceste constatări, identificarea variabilelor legate de calitatea scăzută a vieții experimentată de către persoanele paraplegice poate fi utilă în modificarea protocoalelor de reabilitare $\mathrm{cu}$ scopul de a reduce diferența dintre nivelul calităţii vieţii între persoanele paraplegice și cele fără leziuni medulare.

Deși activitatea fizică crescută îmbunătăţeşte nivelul funcţional după lezionarea măduvei spinării [7], a fost observat un nivel de activitate fizică mai mic la persoanele cu această patologie [8].

Această scădere a activității fizice după lezionarea măduvei spinării poate avea la bază factori psihologici, pierderea funcţiei motorii, o pregătire fizică deficitară pe parcursul perioadei acute de reabilitare, dar și lipsa unor echipamente de fitness adecvate, a unor săli de de kinetoterapie dotate corespunzător sau lipsa unor programe de exerciţii orientate înspre promovarea activităţii fizice, prin urmare, un stil de viață activ nu poate să apară în mod spontan după lezionarea măduvei spinării, iar pacienţii raportează că programele de reabilitare urmate de ei, nu duc întotdeauna la o creştere a activităţii fizice [9].

În schimb, atunci când o stimulare adecvată este realizată prin activitatea fizică, a fost observată o recuperare mai bună a funcţionalităţii $[10,11,12]$, ceea ce indică faptul că ar putea exista o relaţie directă între activitatea fizică și calitatea vieții la persoanele cu leziuni medulare [13].

Rezultatele cercetărilor ştiinţifice şi experienţa practică au demonstrat importanţa practicării exerciţiului fizic, în general, şi sportului, în special, pentru persoanele cu dizabilităţi, ceea ce conduce la ideea că statul şi societatea trebuie să acorde o mai mare importanţă rolului sportului în politica sa socială şi în strategia privitoare la protecţia persoanelor $\mathrm{cu}$ dizabilităţi.

\section{Concluzii}

O abordare kinetică complexă care, iniţial, să surprindă cât mai amănunţit şi exact manifestările variate ale tabloului morfo-pato-funcţional în urma lezionării măduvei spinării prin intermediul unei evaluări specifice, corecte şi competente, şi care, ulterior, să acţioneze cu mijloace specifice în vederea rechilibrării funcţionale, poate îmbunătăţii evoluţia pacientului paraplegic, materializată printro creştere a gradului de activitate fizică cu implicaţii directe asupra nivelului calităţii vieţii acestor persoane.

Absenţa unui mediu fizic complet accesibilizat şi neimplicarea suficientă a societăţii civile în sprijinirea cauzelor persoanelor cu dizabilităţi, favorizează eşecul în integrarea socială ceea ce atrage după sine apariţia la aceste persoane a sentimentelor de inutilitate, frustrare, neputinţă, marginalizare.

Să nu uităm că scopul kinetoterapiei şi/sau al terapiei ocupaţionale este de a învăţa paraplegicul să se ajute singur, ceea ce înseamnă a-1 face să-şi utilizeze la maxim restantul funcţional de care dispune pentru a compensa partea paralizată şi să-şi accepte disabilitatea. Pacientul paraplegic trebuie conştientizat cu privire la faptul că are încă multe resurse de a fi util lui şi celor din jur şi că viaţa poate să-i ofere destule satisfacţii şi în aceste condiţii în care modalitatea de deplasare i se modifică.

$\mathrm{Cu}$ toate că omenirea a cunoscut un progres enorm până în prezent, conform Organizaţiei Mondiale a Sănătăţii (OMS), persoanele cu dizabilități sunt printre grupurile cele mai marginalizate din lume, au o stare de sănătate mai precară, realizări mai modeste în domeniul educaţiei, participă mai puțin la viața economică și au o rată a sărăciei mai ridicată decât persoanele fără dizabilități. Dizabilitatea este acum considerată ca fiind o problemă a drepturilor omului, dizabilitatea oamenilor datorându-se şi societăţii, nu doar modificărilor organismului. [14] 
Societatea a parcurs un lung drum în ceea ce priveşte atitudinea faţă de persoanele cu dizabilităţi. Studierea trecutului ne oferă oportunitatea reflectării asupra ceea ce dorim să dezvoltăm în viitor: o atitudine deschisă, constructivă, de acceptare necondiţionată faţă de aceste persoane, o societate în care se oferă fiecărei persoane şansa unei existenţe decente.

Aceste bariere pot fi depășite numai printr-o conlucrare organizată a guvernelor, a organizațiilor non-guvernamentale, a profesioniștilor din domeniul reabilitării funcţionale și a persoanelor cu dizabilităţi împreună cu familiile sau aparţinătorii acestora.

\section{References}

1) Kiss, I., Fiziokinetoterapia şi recuperarea medicală, Editura Medicală, Bucureşti; 2002, p.268

2) Kiss, I., Fiziokinetoterapia şi recuperarea medicală, Editura Medicală, Bucureşti; 2002, p.270

3) World Health Organization - Measuring Quality of Life, Geneva, CH, 2004.

4) Stevens, Sandy L., Caputo, Jennifer L., Fuller, Dana K., Morgan, D.W. - Physical Activity and Quality of Life in Adults With Spinal Cord Injury, The Journal of Spinal Cord Medicine, American Paraplegia Society; 2008, 31:373-378.

5) Kannisto, M., Merikanto, J., Alaranta, H., Hokkanen, H., Sintonen, H. - Comparison of healthrelated quality of life in three subgroups of spinal cord injury patients, Spinal Cord, Stockton Press, Hampshire, UK; 1998, 36:193-199.

6) Post, M., VanDijk, A., Asbeck, F., Schrijvers, A. - Life satisfaction of persons with SCI compared to a population group, Scandinavian Journal of Rehabilitation Medicine, Scandinavian University Press, Stockholm; 1998, 30:23-30.

7) Merzenich, M., Taub, P., Greenough, T. Neural plasticity, Harvard Brain; 1999, 16:16-20.

8) Buchholz, A.C., McGillivray, C.F., Pencharz, P.B. - Physical activity levels are low in free-living adults with chronic paraplegia, Obesity research, North American Association for the Study of Obesity, Silver Spring, MD, USA; 2003, 11:563-570. 9) Levins, S., Redenbach, D., Dyck, I. Individual and societal influences on participation in physical activity following spinal cord injury: $A$ qualitative study, Physical Therapy, American Physical Therapy Association, Alexandria, VA, USA; 2004, 84:496-510.

10) Maenpaa, H., Jaakkola, R., Sandstrom, M., Airi, T., Von Wendt, L. - Electrostimulation at sensory level improves function of the upper extremities in children with cerebral palsy: a pilot study,
Developmental medicine and child neurology, National Spastics Society Medical Education and Information, London, UK; 2004, 46:84-90.

11) Dobkin, B. et al. - The evolution of walking-related outcomes over the first 12 weeks of rehabilitation for incomplete traumatic spinal cord injury: the multicenter randomized spinal cord injury locomotion trial, Neurorehabilitation and neural repair, Sage Publications, Thousand Oaks, CA; 2007, 21:25-35.

12) Fouad, K., Pearson, K. - Restoring walking after spinal cord injury, Progress in neurobiology, Pergamon Press, Oxford, NY, USA; 2004, 73:107126.

13) Stevens, Sandy L., Caputo, Jennifer L., Fuller, Dana K., Morgan, D.W. (2008) - Physical Activity and Quality of Life in Adults With Spinal Cord Injury, The Journal of Spinal Cord Medicine, American Paraplegia Society; 2008, 31:373-378.

14) World Health Organization - 10 facts on disability;who.int/features/factfiles/disability/en/, 2013 15) [15] Womelsdorf T, Fries P, Mitra PP, Desimone $R$ (2006) Gamma-band synchronization in visual cortex predicts speed of change detection. Nature 439 (7077):733-736.

16) [16] Pesaran B, Pezaris JS, Sahani M, Mitra PP, Andersen RA (2002) Temporal structure in neuronal activity during working memory in macaque parietal cortex. Nat Neurosci 5 (8):805-811.

17) [17] Hansen BJ, Chelaru MI, Dragoi V (2012) Correlated variability in laminar cortical circuits. Neuron 76 (3):590-602.

18) [18] Abbott LF, Dayan P (1999) The effect of correlated variability on the accuracy of a population code. Neural Comput 11 (1):91-101.

19) [19] Gutnisky DA, Dragoi V (2008) Adaptive coding of visual information in neural populations. Nature 452 (7184):220-224.

20) [20] Barlow HB (1961) Possible principles underlying the transformations of sensory messages. In: Rosenblith WA Sensory Communication MIT Press, Cambridge, Massachusetts, pp 217-234.

21) [21] Sharpee TO, Sugihara H, Kurgansky AV, Rebrik SP, Stryker MP, Miller KD (2006) Adaptive filtering enhances information transmission in visual cortex. Nature 439 (7079):936-942.

22) [22] Salinas E, Sejnowski TJ (2000) Impact of correlated synaptic input on output firing rate and variability in simple neuronal models. $J$ Neurosci 20 (16): 6193-6209. 